\title{
The Production of Caustic Alkali and Bleach ${ }^{*}$
}

\author{
A Review of Recent Developments
}

By D. J. Allmand, D.Sc.

Tне most important advances made in late years in the technical electrolysis of alkaline chlorides for the production of caustic alkali and chlorine are perhaps due to Dr. Jean Billiter, privatdozent in the University of Vienna. Some years back he designed a diaphragm cell which is he has invented a modified form of the well known bell-jar cell, which is undoubtedly, taken all in bell-jar cell, which is undoubtedly, taken all in
all, one of the most efficient cells now operated all, one of the most efficient cells now operated
technically. The Billiter-Siemens diaphragm cell I propose to mention briefly only, as full accounts of it are available elsewhere, and shall devote most attention to the Billiter "membrane" cell, the first installation of which started work early this year.

$$
\text { BILLITER-SIEMENS CELL. }
$$

Most diaphragm cells in technical use have vertical diaphragms (e. g., Hargreaves-Bird, Townsend, Finlay). Billiter, however, has returned to the use of horizontal diaphragms such as wer formerly employed by Le Sueur and by Carmichael. He has compared elsewhere the relative advantage and disadvantages of the vertical and horizontal arrangements.

A horizontal diaphragm is more slowly attacked chemically, as it remains more or less saturated with the alkali which migrates upward from the cathode situated immediately underneath. This is particularly important when making strong alka line liquors. Further, the hydrostatic pressure on it is uniform at all points, not varying with th height as in vertical diaphragms. This means a more uniform fow of liquid through, and consequently a more efficient checking of the movement of the $\mathrm{OH}$ ions toward the anode.

There are corresponding structural disadvantages. The floor-space needed is greater. Further, the insides of the cells are less easily accessible and the anodes are necessarily of more complicated construction.

The active diaphragm material in the Billitersiemens cell consists of a mixture of asbestos wool and $\mathrm{BaSO}_{4}$, spread out evenly on top of a sheet of woven asbestos cloth, which in its turn rests on the ironwire net-work which constitutes the cathode. The function of the asbestos cloth merely to support the $\mathrm{BaSO}_{4}$ mixture and to prevent its being displaced by the lively hydrogen evolution. The cathode makes contact with th iron bottom of a trough, the sides of which ar lined with cement, and the anode chamber i formed by a non-conducting bell-jar, which is securely cemented around the edges of the diaphragm. An important feature of the cell is the arrangement for heating the electrolyte by means of earthenware pipes through which hot liquids of earthenware pipes through which hot liquid run, these being
of the bell-jars.

of the bell-jars.
Cells have been made carrying up to 3,000 amperes at a current density of 4 to 6 ampere per square diameter. Working at 89 to 90 degrees, 12 to 16 per cent $\mathrm{NaOH}$ or 18 to 20 per cent $\mathrm{KOH}$ can be made at a 95 per cent cathodic currency, employing 3.5 volts. An interesting laboratory study of the Billiter-
Siemens cell has been recently published by Muhlaus. $\mathrm{He}$ finds that the $\mathrm{BaSO}_{4}$ used for the diaphragm is best precipitated hot. No change of size of grain when in the hot liquors of the Billite cell is then likely to take place, and a regula and uniform flow is thus assured.

The highest current density permissible is about 6 to 7 amperes per square decimeter.

Above this limit, disintegration sets in. Using 30 to 32 per cent brine at ordinary temperatures, 30 to 32 per cent brine at ordinary
the following figures were obtained:

\begin{tabular}{|c|c|}
\hline $\begin{array}{l}\text { Concentration } \\
\text { of Alkali. }\end{array}$ & $\begin{array}{l}\text { Current Efflciency } \\
\text { Per Cent. }\end{array}$ \\
\hline $3 n$. & ..98-99 \\
\hline & $.95-97$ \\
\hline $5 n$. & . . . . 80-85 \\
\hline
\end{tabular}

The chlorine gas fell in purity from 99.5 per cent to 92 per cent as the alkali concentration was increased. The oxygen produced exceeded the amount of $\mathrm{CO}_{2}$. The solid caustic resulting contained considerable quantities of $\mathrm{NaClO}_{3}$ if pro-

* Paper read before the Faraday Society in London. duced from liquors stronger than $4 \mathrm{n}$. The best results on the whole were given when making $4 \mathrm{n}$. $\mathrm{NaOH}$ at a current density of 4 amperes per square decimeter. Raising the working temperature to 70 to 80 degrees improved both energy efficiency and purity of alkali.

The Billiter-Siemens process is now operated as follows:

(a) In Aschersleben, Saxony, by the Kaliwerke schersleben A. G. Ten 2,000-ampere units.

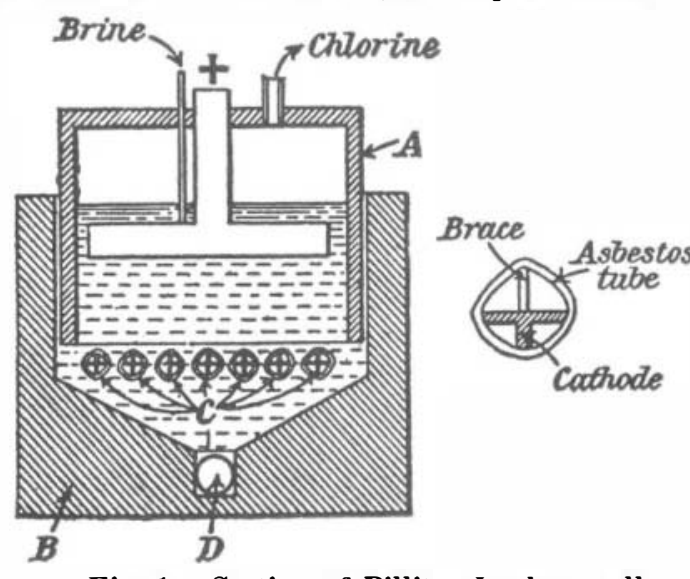

Fig. 1.-Section of Billiter-Leykam cell.

(b) In Höchst, by the Farbwerke Höchst. (c) In Brückl, Bosnia, by the Bosnische Elektrizitäts A. G. Sixty-fou 2,500-ampere units.

(d) In Krumau, Bohemia, by Ignaz Spiro and Söhne. Thirty-two 500-ampere units.

(e) At Niagara Falls, by the Niagara Alkali Company. A 1,000-kilowatt installation of 3,000ampere units.

A number of plants are also being installed or enlarged. The Niagara Alkali Company (which has succeeded the old Roberts Chemical Comfrom 1,000 to 3,00 ) kilowatts. It has also been made known that a now factory for caustic alkali made known that a now factory for caustic alkali
and bleach is being erected, commencing with 78 and bleach is being erected, commencing with 78 installing twenty-four 100-ampere units

$$
\text { BILLITER-LEYKAM CELL. }
$$

In this cell Billiter has successfully modified the bell-jar process, placing the cathodes (hooded to collect the hydrogen) immediately underneath the bell-jar, and not around its sides, as in the Aussig cell. Similar constructions had been formerly suggested by Richardson and by Bein, but had gested by Richardson and
achieved no technical success.

By doing this, Billiter gains an important advantage. In the ordinary bell-jar, both flow of liquid and flow of current change in direction at the

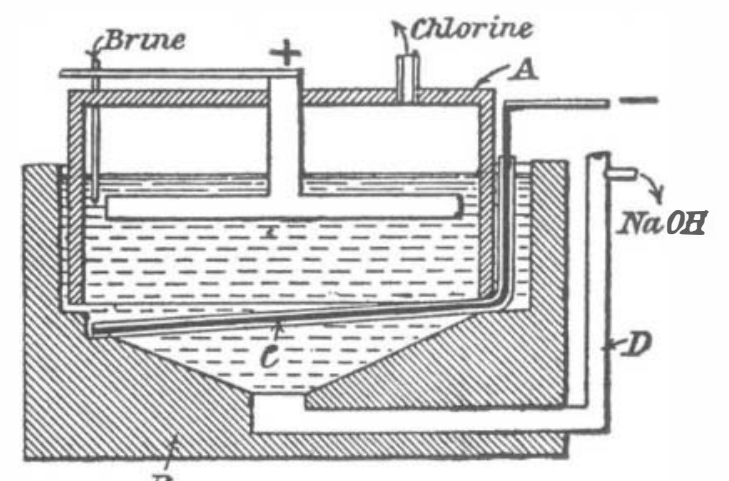

$B$

Fig. 2.-Section of Billiter-Leykam cell.

lower edge of the bell-jar. This results in nonuniformity of current density and liquid flow in the different parts of the bell-jar section. At some points liquid will be flowing more quickly than is necessary to overcome the $\mathrm{OH}_{1}$ migration toward the anode, at other points the contrary will be true; the movement of the $\mathrm{OH}^{\prime}$ ions will predominate, and the current efficiency will fall. This last statement particularly holds for those parts of the bell-jar section farthest removed from the walls, where the current of liquid is exceedingly slow. The larger the bell-jar, the greater prorapidly with current density. It also increases that the units (bell-jars) at Aussig are very small, and can only be worked at a low current density, furnishing weak alkali. Such a plant requires much foor space for its output and the labor charges are high.

In the Billiter cell, this change of direction and the resulting irregularities are avoided, the motion of the brine being directly opposed to that of the current lines until it has passed the cathodes. The consequence is that high current densities can be used, stronger caustic liquors produced, high current efficiencies obtained, and large units constructed. At the same time, the advantage of the bell-jar cell, the absence of diaphragms, is essentially retained. For, though the current must al pass through the hoods which cover the eathodes, this is not true of the electrolyte. Most of it passes directly through the spaces between neighboring cathodes, and is charged with caustic by diffusion from the concentrated alkali which fills the cathode hoods. Not only does this alkali protect the hood material (in practice, woven asbestos) against chemical action of chlorine compounds, but suspended matter present in the brine is not filtered out, as happens in diaphragm cells, and it is not necessary to purify the brine in any way. The asbestos hoods are made of as coarse a structure as is consistent with their function of leading off the hydrogen gas, and affect the voltage to a very slight degree only. Finally, the cell is heated in a similar fashion to the the cell is heated in a similar fashion to the

The essential parts of the Billiter-Leykam cell are shown diagrammatically in Figs. 1 and 2 . A is the bell-jar inverted in the cement trough $\boldsymbol{B}$ and provided with anode outlet for chlorine, inlet for brine and heating arrangement. The cathodes $C$ are arranged below the bottom level of $A$ and consist in practice of T-iron. They are inclosed separately in long woven asbestos tubes which are suitably braced in order to avoid deformation by the evolved hydrogen, and are slanted sufficiently to allow the gas to stream away readily. These cathodes project out into a side compartment of the cell as shown, from which the hydrogen can, if necessary, be collected.

The causticized brine flows off through $D$.

The Austrian rights to the Billiter bell-jar cell have been purchased by the paper manufacturers Leykam-Josefsthal A. G. The first plant has been erected in their mill at Gratwein, a village on the Austrian Southern Railway, a few miles from Graz, has been in continued operation since early 1912 , and has given every satisfaction. Some 1,700 to 1,800 kilos of active chlorine are produced daily, and the whole plant uses about 400 P. S. -350 P. S. for the cells and 50 P. S. for auxiliary pumps, fan, etc. Power is purchased from a company at $150 \mathrm{kr}$. (\$31.25) per P. S. year. After converting into direct current, and reckoning all losses in leads, etc., the cost comos to $180 \mathrm{kr}$. $(\$ 37.50)$ per P. S. year.

The plant consists of 561,200 -ampere units, 50 of which were working at the time of $\mathrm{my}$ visit last July.

The cells are 5.5 meters long, 1.1 meters broad (internal measurements), and about 1.3 meters high. The side walls commence to slope inward about 70 centimeters below the top of the cell. They are built of reinforced concrete, the upper part being lined with earthenware bricks set in part beint.

They are provided with three cement lids, each of which carries eight anodes.

The anodes are of Acheson graphite $(1.0 \times 0.18 \times$ 0.05 meter), each being led through its lead by means of two graphite rods. The lids are cemented on to a shallow shelf cut out of the wall of the cell by means of ordinary putty, which stands the action of chlorine very well and always remains fairly soft. Putty is also use at the points where the anodes pass through the lids, as the weight of the anodes is not borne by the latter, but by the copper leads above. Each anode takes 50 amperes at a current density, assuming lower and side surfaces. to be active, of about 1.6-1.7 amperes per square decimeter.

The cathodes are of T-iron and inclosed in woven asbestos tubes. These taper down slightly toward their closed lower ends, and the whole is braced by the insertion of a wedge-shaped strip of asbestos cement. The tubes pass through holes in the 
dividing wall into the side compartment of the cell as indicated in Fig. 1. Two iron rods attached to each T-iron cathode take the current to the copper leads above. The hydrogen is allowed to escape. The cathodes are, of course, about meter in length, and the mean breadth of th asbestos tubes is about 5 centimeters. Between each tube there is a space of 5 to 8 millimeters. The upward slope of these tubes is about 2 centimeters per meter,

The brine (moving from a reservoir under gravity) is led to a distributing box situated above the cells. From this it proceeds by way of series of short capillary tubes (1.5 millimeters bore) to 22 -inch tubes, which pass through th cell lids, and is thus fed in between the anodes. Regulation of the main supply to the cell is effected by means of a rubber tube and clip. factorily, though the capillaries sometimes get factorily, though the capilaries sometimes get
stopped up. The causticized brine is drawn of stopped up. The causticizd brine is drawn off
from one side of the cell by means of siphon overfrom one side of the cell by means of siphon over-
flows. Three are provided, but one only is used flows. Thre

The heating arrangement used by Dr. Billiter
The in his diaphragm cell, though available for all other installations of his "mombrane" cell, canno be used at Gratwoin. ('The patent rights are not there available). The cells are, therefore, provided with a heating arrangement which employs steam, the details of which, however, I cannot divulge here. When I was at Gratwein, the cells were being mostly worked at room temperature while those few which were being heated wer working at a temperature of 65 deg. Cent. to 70 deg. Cent.

The cells are arranged in four rows, two row being worked in series, and are insulated by glass resting on concrete supports. Beneath the cells are arranged the chlorine and brine pipes, and channel for the caustic liquors. The chlorine pipe-
line is constructed of cement, junctions being made line is constructed of cement, junctions being made
by covering the ends with a coment box and filling up with asphalt. The current leads are of copper, those connecting the cells of circular cross-sectio and 3 centimeters in diameter. They are all painted with a composition stable against chlorine and acid fumes, as are also the tin tubes and rubber connections referred to above. The cells
are worked under slightly reduced pressure (1/2 centimeter of water), and, as a matler of fact, no smell of chlorine was noticeable. Ventilation can be effected, if necessary, by blowing air in through the agency of a fan driven by a horsepower motor. A traveling-crane is provided to facilitate lifting off the tops of cells, etc

Saturated brine is used, prepared in the simplest way. A long cement trough is filled with large lumps (20 to 40 centimeters) of crude salt. Waters enter continuously at one end, and saturated brine leaves at the other. It is not purified, and can leaves at the other. It is not purified, and can
be sent straight to the cells. The average cathode liquors produced contain 12 to 13 per cent $\mathrm{NaOH}$ and about 20 per cent $\mathrm{NaCl}$. By decreasing the rate of flow of brine, 16 per cent $\mathrm{NaOH}$ can readily be made. Up to 350 liters of brine per cell are causticized in 24 hours. The liquors are first evaporated in two vacuum pans, furnished by the Skodawerke A. G., Pilsen, and similar to by the Skodawerke A. G., Pilsen, and similar to
those used in sugar refineries. In these they are successively brought to $30 \mathrm{deg}$. Bé. and $40 \mathrm{deg}$. Bé. Then by means of a Kaufmann rapid evaporator they are brought to $50 \mathrm{deg}$. Bé. before going to the melting-house. The final product, which will probably be later somewhat improved upon, contains 97 per cent $\mathrm{NaOH}, 1.2$ per cent $\mathrm{Na}_{2} \mathrm{CO}_{3}$, and 1.8 per cent $\mathrm{NaCl}$. The chlorine is diluted and absorbed in milk of lime.

Cells which are worked at room temperature take abøut 4 volts. Those I saw working at 65 to 70 degrees require 3.4 to 3.5 volts. Long continued experiments carried out with a 250-ampere unit have shown that at the normal working temperature of 85 degrees the voltage falls to 3.1 volts (plus in all cases the voltage drop in the leads). The cathodic current eff

It remains to be added that wear and tear in the cells are very small. Under normal working conditions the anodes lose about 1 millimeter in thickness at their bottoms and sides in two months. Suspended matter in the brine settles on the bottom of the cells, and the asbestos hoods remain un-
affected. Finally, when once matters are adjusted, the whole system works automatically. The actual cell-room in Gratwein is worked by shifts of one workman only, whose duty it is to adjust the rates of flow in the different cells. Moderate fluctuations in rate of flow of brine or in current density result in a change in the alkalinity of the liquors produced, and in a corresponding small change in current efficiency. The cells at Gratwein work at a current density between the electrodes of about 2 amperes per square decimeter only. With cells working at 85 degrees the most convenient figure, according to Billiter, is 4 to 6 amperes per square decimeter; but, by suitably varying the other conditions, 14 amperes per square decimeter can be employed.

The withdrawal of 350 liters of catholyte per cell per 24 hours corresponds to a movement of the brine of about 0.00007 centimeter per second. The $\mathrm{OH}$ ions in that part of the catholyte between just about the same magnitude. (E. g., assuming the cell to work at room temperature, the conductivity of the electrolyte would be about 0.5 reciprocating ohm per cubic centimeter, the velocity of the $\mathrm{OH}$ ion at a voltage gradient of 1 volt per centimeter, 0.0018 centimeter por second, and
the actual velocity $0.02 \times 0.0018 \div 0.05=0.000072$ centimeter per second). This elose approximation between the two opposing velocities, with the consequent straying of $\mathrm{OH}$ ions toward the anode, is of course the chief cause of the 8 per cent deficiency in current efficiency, as the amount of chlorine which dissolves in the concentrated brine, and which would thus tond to be carried to the eathode, is very small.

In conclusion, I will again emphasize the chief characteristics of the Billiter-Leykam cell. They

(1) Freedom from diaphragm troubles.

(2) Use of impure brine.

(3) Automatic working, great adaptability, and low attendance charges.

(4) Alkali (3n to $4 \mathrm{n}$ ) strong eompared with most ther non-mercury cells.

(5) With heated cells, lowest energy consumption per ton of product of any of the electrolytic cells now working on a large scale.

\section{Regulation of the Heat of the Body in Hot} Climates*

$I_{N}$ all temperate climates and, if certain exceptional cases are noted, in almost all climates in which mankine is engaged in the usual activitios of life, the temperature of the human body is higher than that of the environment, so that there is a tendency toward continuous loss of heat from the surface of the body. Except in so far as it is prevented by the insulating devices of clothing this loss takes place in part by convection, that is, by warming the layers of air in contact with the body, as well as by radiation wherchy there is an exchange of heat between the surface of the body and that of sur-
rounding cooler objects. When there is occasion for the rounding cooler objects. When there is occasion for the
removal of a larger amount of heat, this is accomplished through the function of perspiration. In the evaporation of sweat a large amount of heat becomes latent and is removed from the body. The chief factor which may interfere with this procedure is the impeding of th evaporation by the presonce of an atmosphere already saturated with water vapor so that the sweat can no longer be converted into the gaseous phase.

Few persons realize that there are, nevertheless, inhabited regions in which the temperature of the surrounding air is not lower than that of the body. In parts of India, for example, during the hot weather in March, April and May, the maximum temperature is daily seldom under 38 deg. Cent. (100.4 deg. Fahr.), and in som places it rises to over 43 deg. Cent. (109.4 deg. Fahr.) for long periods. Usually such habitable areas experience a very low percentage of moisture in the air. We heat is not usual, since with the rains the weather becomes cool.

It is well known that the body temperature can be maintained at its normal height in an atmosphere much higher than 37 deg. Cent. (98.6 deg. Fahr.), in spite of the fact that the production of heat is still going on in the organism. It is said that a man can stand exposure to a temperature of 90 deg. Cent. (194 deg. Fahr.) or even 120 deg. Cent. (248 deg. F'ahr.) for a considerable time provided that the air is dry. If the outside temperature be above that of the body, heat is actually added instead of lost; and this additional hea is greatly increased by exposure to a very hot sun or wind. Inasmuch as radiation and conduction are availture is below that of the body, it is a matter of no little moment to understarid what the organism is called on to $*$ Reproduc
Association. do in order to prevent any marked rise of internal temperature. That an adjustment does take place is assured from the fact that during extremes of dry heat no great discomfort is felt by healthy persons; and it is stated on good authority that fairly hard physical work is possible in the sun, even with a "shade" temperature organism must depend solely on evaporation as a cooling agent; and this function must be sufficient to remove agent; and this function must be sufficient to remove
all the heat added from external sources as well as the all the heat added from external sources as well as the
heat due to internal metabolism. In a Turkish bath heat due to internal metabolism. In a Turkish bath
the loss of weight, represented almost entirely by water, may be at the rate of at least two pounds every hour.

Dr. E. H. Hunt, medical officer to the N. G. S. Railway, who resides in Decean, India, where extremes of heat like those mentioned prevail, has furnished interesting data as to how one becomes adjusted to the physiologic and hygienic conditions thus created.1 The physiologic and hygienic conditions thus created. ${ }^{1}$ The
heat contributed by the combustion of the ordinary foodsupply sufficient to maintain nutritive equilibrium may be judged from its fuel value. If this is put at 3,500 calories for an active working man, a calculation shows that the amount of water the evaporation of which will absorb this heat at body temperature is 6 liters (about 6 quarts). Water must therefore be taken into the body in food and drink to supply this requirement in addition to what is lost by excretion, is wasted by inefficient perspiration, or is needed to remove the heat actually added to the body from without, in the hot climates referred to.

Such hypothetical estimates have been compared by Dr. Hunt in India with actual observations made during an exceedingly hot and very dry period when, for some hours at midday, the lowest temperature which could be secured in tents under trees was 42.8 deg. Cent. (109 deg. Fahr.). All dry objects were as hot as this or hotter and were uncomfortable to handle. The mercury in the thermometer fell at once when a hand was placed near it, or if it were breathed on. Until about midday
the party of investigated healthy Europeans remained the party of investigated healthy Europeans remained
in the sun with no shade whatever, a considerable amount of physical exercise being taken. Such a life, we are told, is led by hundreds of Europeans in India, customarily with a gain rather than a loss of health. When health suffers it is usually through the incidence of infectious disease. None of the party, using strict moderation, consumed less than three gallons of liquid ${ }^{1}$ Hunt. E. H.: The Regulation of Body Temperature in Ex tremes of Dry Heat, Jour. Lyy.., 1912, xii, 479. per day. When the activity and considerable exposure to the extremes of heat are taken into account in this experience, which probably represents an approach to the limit of comfort, the fluid intake is not far removed from the hypothetical estimate, based on the many data at hand.

It is obvious that in such extremos of dry heat any failure of perspiration must lead to instant and grave risk. This failure may result from an insufficiency of drinking-water. It may equally result, as Dr. Hunt maintains, from pathologic processes incident to slight malaria, early typhoid, or any other process by which heat regulation is upset. He adds that he has not come across any case of pure "heat-stroke" or sunstroke in proved healthy person. A man might suffer from but slight fever while indoors and night be unaware that he was ill; yet his whole regulation might completely fail if he were at work in the sun under the numerous conditions which involve an extreme effort even for the healthiest.

The main regulation of heat loss takes place by the control of the nervous system over the cutaneous circulation and the sweat-glands. When this fails, the tem perature must speedily rise above the normal in these hot climates. General excitability is evinced and metabolism is stimulated so that a "vicious circle" is established. There is not even any compensation by lessened heat production. In "wet heat" the limit of safety is speedily reached. When the air is already more or less speedily reached. When the air is already more or less
saturated with moisture, as indicated by high wet-bulb thermometer readings, evaporation is slow and inefficient, and danger ensues even during rest. The excess of sweat secreted and any increase in the amount of water consumed under such conditions merely increase discomfor rather than facilitate the p oper heat regulation of the body.

The large amount of wator absolutely required and actually consumed by men in these hot climates has not been appreciated adequately in any quantitative sense. Experiments by Hunt have demonstrated that healthy man carries in his body a large reserve of water mainly stored in muscle and so readily available that th percentage of water in the $\mathrm{b}$ ood is not apprecably diminished even when several liter: of water have been lost by sweating. If, however, it is extensively drawn on, replacement seems to occupy many hours, and this delay is an important factor, forming a strong argument against any restriction of drinking which would cause undue or necdless use of the stored water of the human body. 